ОГЛЯДОВї ТА ТЕОРЕТИЧНї СТАТТ İ

OBSERVATION AND THEORETICAL ARTICLES

УДК 579.25:632.35:634.8.03/.05

\title{
N. Limanska
}

Odesa National Mechnykov University, 2, Dvoryanska str., Odesa, 65082, e-mail: limanska@gmail.com

\section{PREVENTION OF GRAPE CROWN GALL}

Complex strategies to control crown gall are reviewed: indexing of planting material, hot water treatment, cultural practices, treatments with chemical substances and plant extracts. Special attention is paid to the biological control. The short descriptions of the most well studied antagonistic strains are listed. The main problems of grape crown gall prevention are elucidated.

Key words: crown gall, grapevine, Agrobacterium vitis, Agrobacterium tumefaciens.

Crown gall of grape is one of the most dangerous diseases in commercial nurseries of many grape-growing countries. On the young vineyards of susceptible cultivars up to $75 \%$ of the plants may die from galls surrounding the trunks and interfering the normal water and nutrients supply [14]. In adult plants crown gall strongly affects grapevine growth and makes plants less resistant to unfavorable environmental conditions. Early decline of grapes also occurs [13]. This leads the investigators to develope the effective means of crown galled plants treatment and disease spread prevention.

Crown gall of grape is caused by Agrobacterium vitis (Rhizobium vitis by recently proposed nomenclature [106]) and in some cases - by A. tumefaciens (R. radiobacter) $[13,59]$. Pathogenic agrobacteria have the ability to transfer the definite segment of Ti plasmid into eukaryotic cells, where it integrates into the genome $[21,40]$. Pathogens induce crown gall tumors on the representatives of 93 families of dicotyledonous plants [27], but grape, stone fruits and ornamentals are the most being suffered [13, $38,65]$.

Crown gall agents survive in grapevine xylem and are transmitted by vegetative propagation [60]. If infected plants remain symptomless for a long time, they may be used by mistake as planting material, and this results in further spread of pathogens and consequent losses in viticulture [10].

(C) N. LIMANSKA, 2012 
Pathogenic agrobacteria penetrate into grapevines through the wounds caused due to planting, grafting, pruning, or through the wounds made by nematodes $[38,88]$. A. vitis survives in soil in plant debris opposite to A. tumefaciens which is a typical soil saprophyte [13].

None of the modern control methods results in complete pathogenic agrobacteria eradication, and appropriate control of crown gall for every stage of viticulture is needed.

The first stage includes selection of pathogen-free plants for vegetative propagation, indexing and certification of propagation material. Grapevines have differences in their susceptibility to crown gall infection $[37,89,90]$. Susceptible rootstocks and cultivars may maintain populations of crown gall agents and therefore their planting is not recommended especially in the regions with spring frosts [39].

The highly specific and rapid diagnostics methods are necessary to ensure healthy planting material selection.

Polymerase chain reaction (PCR) [81] is the most widely used method for crown gall disease diagnostics, it was started to use in the end of 1980s - beginning of 1990s [30].

To detect pathogenic agrobacteria species the primers to Ti plasmid sequences have been employed, for example, FGP $t m r 530$ and FGP $t m r$ 701 from the T-DNA region, FGP vir $\mathrm{B}_{11+21}$ and FGP vir G15 from the intercistronic region between vir $\mathrm{B}$ and vir $\mathrm{G}$ in the virulence region of the $\mathrm{pTi}$ [68]; VCR/VCF from the vir $\mathrm{C}$ of $\mathrm{pTi}$ [82]; vir A primers specific for the virA region, $6 a$ primers specific for $6 a$ gene in pTi [32]; virC primers specific for the $\operatorname{vir} C$ region, vir $E_{2}$ specific primer pair [92].

There are also known the primers for sequences of chromosomally localized genes, for example, pehA primers from hydrolase gene [32, 46], PGF/PGR primers for detection of polygalacturonase gene sequence [46, 92], primers Ab3-F3/Ab3-R4 or F63r16S/F153r16S to specific sequences of $A$. vitis $16 \mathrm{~S}$ rDNA $[1,52,73]$.

The investigators offer various primer pairs allowing not only to distinguish crown gall agents among other bacterial species but to detect various opine types of agrobacterial strains [7, 16, 76, 84, 92, 93].

PCR with vir $D_{2}$ and ipt primers to the sequences of genes encoding endonuclease and isopentenyltransferase [41] were applied for the production of clean planting material of asters and roses and showed excellent results [65].

Kumagai L. and Fabritius A.-L. (2008) in comparative study of different primers showed the best results for $A$. vitis and $A$. tumefaciens detection in grapevines for primers pare VCF3/VCR3 elaborated by Suzaki et al. (2004) [58, 91].

Due to genetic variability of different agrobacterial strains, the use of multiplex PCR with mixtures of virulence-, or oncogene specific primers is 
recommended for the most precise pathogen detection [8]. It was proposed to apply the internal control for effective diagnostics of crown gall [25].

There are two ways in DNA-diagnostics of crown gall agents. The first means initial isolation of bacterial cultures on semi-selective media and testing of the isolated strains in PCR (BIO-PCR) [41, 65, 83]. Immunocapture of agrobacteria followed by PCR with the DNA of retained cells was proposed [51].

The second way means isolation of total DNA and use of such DNA sample for amplification of certain sequences [24, 32, 57, 77]. During PCR-evaluation of bacterial quantity in tumour, it should be taken into considereation that the primed sequence of pathogenic agrobacteria plasmid gene is also incorporated in plant cell DNA [24].

Both ways have their advantages and disadvantages and can be used in indexing of disease-free propagation material.

Pathogenic Agrobacteria strains are relatively difficult to differ from certain types of tumors in which nonpathogenic agrobacteria prevail. The investigators showed that five different $A$. tumefaciens strains initially isolated from apple tumors produced up to $99 \%$ nonpathogenic mutants following their introduction into plants [5]. Other authors [62] studied tumours in apple, tomato, pepper, plume, cherry, pear and peach, and revealed much smaller amount of mutant strains $(0.01 \%)$ present only in tomato and pepper tissue. This process has not been studied on grapevines yet.

To prevent the spread of grape pathogens in propagation material nurseries apply hot water treatment (HWT) [98, 99]. HWT is highly recommended to serve as the second stage of crown gall control - the stage concerning propagation material production.

Hot water treatment, or heat treatment means submersion of plant material in hot water for a fixed period of time. HWT is widely used in many countries to eliminate pathogens and pests from dormant grapevines. HWT eradicates or reduces nematodes, phylloxera, mealybugs [43], phytoplasmas and eggs of their vectors [17] and other pests.

Elimination of endogenous pathogens such as phytoplasmas and crown gall agents requires longer duration of HWT opposite to external pests (phylloxera and nematodes) for which shorter duration treatment $\left(52{ }^{\circ} \mathrm{C}-\right.$ $55{ }^{\circ} \mathrm{C}$ for $5 \mathrm{~min}$ ) is sufficient for eradication. In case of long duration HWT danger of bud mortality exists. Burr et al. (1996) [11] observed bud damage when dormant cuttings were treated at temperatures greater than $50{ }^{\circ} \mathrm{C}$. Treatment of samples above $54{ }^{\circ} \mathrm{C}$ for 30 min revealed seasonal and cultivar variabilities in heat tolerance [101]. Therefore standart regimes of $50{ }^{\circ} \mathrm{C}$ for 30 min or $50{ }^{\circ} \mathrm{C}$ for $45 \mathrm{~min}$ are highly recommended for nurseries [11]. Such HWT significantly reduces the quantity of infected plants - to $2 \%$ with galls compared with $60 \%$ of non-treated $[11,70]$. Other investigations also reported about eradication of $A$. vitis or reducing of its population below 
the level of detection [64], but the further testing of grapevines planted in fields after HWT is needed for the final conclusions.

Agrobacteria are non heat resistant bacteria. Continuous growth at $37^{\circ} \mathrm{C}$ or $42^{\circ} \mathrm{C}$ triggers synthesis of heat shock proteins [3]. But the problem is that the temperature regime $50{ }^{\circ} \mathrm{C}$ is not sufficient for complete eradication of crown gall agents in the plants. Cells of $A$. vitis surviving in dormant grape cuttings are more heat-tolerant than cells grown in culture in stationary phase. Internal tissues of the cuttings reach the temperatures of water bath within 4-6 minutes, so agrobacteria survival could not be explained by difference in the temperatures [11]. Further studies of variable heat sensitivities of crown agent strains [11,64] and efficacy of HWT in pathogens eradication are needed. But the problem is that if the wound tissue has been already transformed before heat treatment, eradication of agrobacteria will not prevent from crown gall development.

Contaminated soil, water and the instruments may result in reinfection with phytopathogens in an open field nursery [98].

The third stage of crown gall control means prevention of plant tissues from pathogen penetration, or treatment of infected grapevines to reduce the symptoms or decline, and to avoid spread of infection from the diseased plants to the healthy ones. This includes the special cultural practice with choosing non-infected plot with non-heavy soils, without excessive wet, which is not situated in low-lying lands. It also is better to use potassium fertilizers instead of nitrogen ones to improve resistance of grapevines to cold [13]. Fumigation decreased level of infection on vineyards. Combined treatments with antagonistic strain $A$. radiobacter HLB-2 and fumigant Vorlex had a synergistic effect on crown gall control [75].

Population densities of pathogenic agrobacteria declined within solarized plots, and incidence of crown gall on cherry rootstocks in solarized plots was reduced significantly [72].

There are some cultural practices, which help to destroy fresh tumors by chemicals such as $5 \%$ copper sulfate, Bordeux mixture plus 4,6-dinitroo-cresol or by pregrafting treatment of oxyquinoline sulphate [13]. The effects of preparation based on walnut extract, and different concentrations of cartacide were studied with positive results [56]. In general, the control of endogenous pathogens is difficult since the traditional techniques such as chemical sprays and soaking used for the control of surface pathogens do not allow to penetrate dormant grapevine cuttings sufficiently to control microorganisms inhabiting the phloem and xylem tissue [98]. The same difficulties exist also for the treatments with the plant extracts.

Extracts of Orobanche inhibited the growth of crown gall agents [80]. The high antitumor activity of Fagonia cretica extracts was found against all the tested agrobacterial strains on a model of potato tuber discs, however, the extract did not show any lethal activity against these strains [49]. Pothomorphe peltata extracts showed $22 \%$ of crown gall inhibition [67], 
extracts from Ludwigia hyssophila -73.5 and $84.14 \%$ inhibition, and extracts from this plant also exhibited a moderate antibacterial activity [26]. Treatment with Albizzia lebbeck extracts resulted in significant decrease in tumor formation too [42].

To retard certain stages of crown gall pathogenesis, the effect of phytohormone salicylic acid was studied. Nicotiana benthamiana plants treated with salicylic acid showed the reduced disease symptoms [2].

Treatment with antagonistic bacterial strains is a very promising trend. As opposed to chemicals, using of antagonistic strains does not interfere the balance in biocoeones. Antagonists colonize the plant tissues as effectively as pathogens do, and have clear stimulating effect on the plants [4]. Antagonistic strains can be easily applied in nursery practice by submersion of the roots of young grape plants and cuttings into cell suspension before planting. A. rhizogenes strain K84 is widely used against A. tumefaciens. The strain can survive in a field environment for at least two years [87]. A. rhizogenes K84 produces highly specific bacteriocin agrocin - the analogue of adenine nucleotide [94].

Reader et al. (2005) showed that agrocin K84 acts on leucyl-tRNA synthetase of susceptible cells, while the producer itself survives by means of the second own synthetase copy [78].

But this bacteriocin is effective only against nopaline, agrocinopine, and succinamopine strains, and therefore has no effect on crown galls on grapevine caused by octopine and vitopine $A$. vitis strains [44, 54]. In some cases the use of $\mathrm{K} 84$ is effective against gall formation caused even by agrocin-resistant strains [71].

A. rhizogenes K84 carries three plasmids - pAgK84 responsible for agrocin K84 synthesis [85], pAgK434 with genes of agrocin 434 [31], and pNoc encoding catabolism of nopaline $[22,66]$. Strain K84 synthesizes one more antagonistic substance - siderophore ALS84 effective against agrobacteria at low-iron conditions [71].

Using of $A$. rhizogenes $\mathrm{K} 84$ may be problematic due to possible transfer of pAgK84 into pathogenic strains. Pathogenic strain with pAgK84 becomes insensitive to agrocin and biocontrol fails [97]. The stable Tra - deletion mutant of K84 - the strain K1026 was constructed [50]. This strain is as efficient as K84 and it can control crown gall without reducing the total quantity of pathogens in the root system [97]. It would be perspective to modify other agrobacterial strains to minimize plasmid transfer possibility.

Despite of the fact that pTi i pNoc belong to one incompatibility group, spontaneous transfer of pTi to K84 cells is also possible. Such transfer can be explained by recombination between pTi and pNoc. The resulted transconjugants are at the same time pathogenic and resistant to agrocin K84 [63]. 
Transfer of plasmids belonging to certain incompatibility groups into $A$. tumefaciens cells results in inhibition of oncogenic properties of pathogenic strains [19, 36].

It was shown that agrobacteria can undergo natural transformation under environmental conditions and this also increases their variability [29].

Pathogenic strains can also produce bacteriocins. For instance, A. tumefaciens $\mathrm{J} 73$, biotype 2 with nopaline type pTi synthesized a bacteriocin active against $A$. tumefaciens and A. vitis [104]. Pathogenic strain A. tumefaciens D286 producing bacteriocin agrocin with wide spectrum of action, spontaneously lost its pathogenecity and therefore could be used as a biocontrol agent $[45,109]$.

Potential antagonists of grapevine crown gall agents are the strains from Agrobacterium genus and the representatives of other genera as well. Eastwell et al. (2006) studied the potential of Pseudomonas fluorescens, Bacillus subtilis and Bacillus sp. isolates as biocontrol agents against crown gall in planta. All three bacteria reduced gall size if they has been applied 25 or 86 days before the inoculation with $R$. vitis [33].

Strains of Pseudomonas aureofaciens and P. fluorescens reduced the occurence and symptoms of crown gall on grapevine and raspberry, and the effect was cultivar-depended [55].

Rahnella aquatilis HX2 isolated from vineyard soil showed a significant biocontrol effect. After three years, the amount of diseased plants among those treated with the antagonist was $30.8 \%$ compared to $93.5 \%$ in nontreated plants [18].

Bell et al. (1995) among 851 isolates from xylem sap revealed 24 strains with clear inhibitory effect on $A$. vitis. These antagonists belonged to Enterobacter agglomerans (35\%), Rahnella aquatilis (30\%) and Pseudomonas spp. (35\%) [6].

Rhizosphere bacteria producing the enzyme 1-aminocyclopropane-1carboxylate deaminase (ACCD), which degrades the immediate precursor of ethylene in the plants, are perspective in A. tumefaciens or A. vitis biological control. Treatment with ACCD-producing Pseudomonas putida UW4, Burkholderia phytofirmans PsJN and Azospirillum brasilense Cd1843 strains significantly reduced the mass of $A$. vitis-induced tumours on tomatoes. Transgenic test-plants expressing bacterial ACCD also showed the high resistance to crown gall [96].

Bazzi et al. (1999) [4] treated grapevine cuttings with antagonistic strains $A$. vitis $\mathrm{F} 2 / 5$ [86], A. vitis 1077 - agrocin-minus mutant of $A$. vitis F2/5, A. vitis 523 [12] and A. radiobacter HLB-2 [105]. After 24 hours, the cuttings were infiltrated with a virulent $A$. vitis strain. There were observed 100 times decreasing of pathogen amount in tissue at the graft point. The best results of grafting showed HLB-2 strain [4]. A. radiobacter HLB-2 suppresses tumors by competing for sites and nutrients and producing an 
agrocin-like substance [74]. But in case of $A$. vitis F2/5 the greatest number of discarded vines occurred due to necroses, though F2/5 is the most perspective biological control agent [4]. The matter is that inhibitory activity of this strain against pathogen is not associated with agrocin production and competition for attachment cells. It is directly related to interaction with grapevine [12]. The investigators suggest that F2/5 inhibits normal healing by inducing necrosis in cambium. Callus cells formed in cambium during wound healing are susceptible to transformation by pathogen. Wounds inoculated with F2/5 prior to application of the pathogen did not develop galls due to necroses induced by biological control strain [23]. This mechanism resembles the hypersensitive response [47].

A. vitis $\mathrm{F} 2 / 5$ inhibits crown gall development only on grapevine and not on other plants. Transfer of the stable plasmid pT2TFXK encoding an antibiotic trifolitoxin from Rhizobium leguminosarum biovar trifolii to A. vitis $\mathrm{F} 2 / 5$ extended the antagonistic properties of the latter. A. vitis F2/5 strain became able to reduce tumour formation on Nicotiana glauca and to inhibit the strains resistant to it before [48].

Nonpathogenic strain $A$. vitis isolated from grapevine roots, E26, is effective against crown gall on grapevine caused by $A$. vitis and crown gall on peach and cherry caused by $A$. tumefaciens [61]. The strain produces an antibacterial substance strongly inhibits pathogenic agrobacteria and their attachment to grape cells [103, 107].

Nonpathogenic strain A. vitis VAR03-1 isolated from nursery stock of grapevines was tested on tomato seedlings and grapevines. The plants were treated with antagonist cell suspension for 24 hours, and after soaked for one hour in pathogen suspension. After the treatments, the test-plants were planted in the pots with infected soil. Significant reducing of gall formation on both tomato and grapevines occurred [53].

The agrocin NA5 active against the close related strains was isolated from the soil born $A$. radiobacter NA5, which was proposed by the authors for the next field trials [69].

The investigations of $A$. vitis spread in feral grapevines showed the interesting results. None of the wild vines studied in Austria were infected with pathogenic agrobacteria [95]. The same results were obtained when feral grapevines of Crimea were tested (Limanska N., Milkus B., personal communication). In Italy, over 50 strains of non-tumorigenic $A$. vitis were isolated from feral grapevines. The transfer of pTi plasmid from pathogenic agrobacteria into nonpathogenic strains from feral grapevines is inhibited [14].

All agrobacteria isolated from feral grapevines in the USA were nontumorigenic as well, and seven strains from 26 studied inhibited pathogen A. vitis K306 [15]. Such investigations point out the possibility to study the strains from feral grapevines as a potential source of antagonistic agents. 
There are few studies concerning agrobacterial bacteriophages and perspectives of their use in biological control of crown gall $[9,20,28,35$, 100, 108]. Eayre C. (2003) informed about the possibility of walnut crown gall control using bacteriophages [34].

Further investigations should be carried out to study the possibilities of biocontrol strains and to search for the new isolates with useful characteristics.

\section{LITERATURE}

1. Al-Karablieh N., Khlaif H., Al-Banna L. Identification of Agrobacterium tumefaciens strains by PCR-RFLP analysis of the 16S-rDNA // Jourdan Journ. Agricult. Sciences. - 2006. - Vol. 2, № 3. - P. 209-220.

2. Anand A., Uppalapati S.R., Ryu C.M., Allen S.N., Kang L., Tang Y., Mysore K.S. Salicylic acid and systemic acquired resistance play a role in attenuating crown gall disease caused by Agrobacterium tumefaciens // Plant Physiol. - 2008. - Vol. 146, № 2. - P. 703-715.

3. Balsiger S., Ragaz C., Baron C., Narberhaus F. Replicon-specific regulation of small heat shock genes in Agrobacterium tumefaciens // J. Bacteriol. - 2004. - Vol. 186, № 20. - P. 6824-6829.

4. Bazzi C., Alexandrova M., Stefani E., Anaclerio F., Burr T.J. Biological control of Agrobacterium vitis using non-tumorigenic agrobacteria // Vitis. - 1999. - Vol. 38, № 1. - P. 31-35.

5. Belanger C., Canfield M., Moore L.W., Dion P. Genetic analysis of nonpathogenic Agrobacterium tumefaciens mutants arising in crown tumors // J. Bacteriol. - 1995. - Vol. 177, № 13. - P. 3752-3757.

6. Bell C.R., Dickie G.A., Chan J.W.Y.F. Variable Response of Bacteria Isolated From Grapevine Xylem to Control Grape Crown Gall Disease in planta // Am. J. Enol. Vitic. - 1995. - Vol. 46, № 4. - P. 499-508.

7. Bini F., Geider K., Bazzi C. Detection of Agrobacterium vitis by PCR using novel virD $D_{2}$ gene-specific primers that discriminate two subgroups // Eur. J. Plant Pathol. - 2008. - Vol. 122. - P. 403-411.

8. Bini F., Kuczmog A., Putnoky P., Otten L., Bazzi C., Burr T.J., Szegedi E. Novel pathogen-specific primers for the detection of Agrobacterium vitis and Agrobacterium tumefaciens // Vitis. - 2008. - Vol. 47, № 3. - P. 181-189.

9. Boyd R.J., Hilderbrandt A.C., Allen O.N. Specificity Patterns of Agrobacterium tumefaciens phages // Arch. Mikrobiol. - 1970. Vol. 73. - P. 324-330.

10. Burr T.J., Katz B.H. Grapevine cuttings as potential sites of survival and means of dissemination of Agrobacterium tumefaciens // Plant Dis. - 1984. - Vol. 68. - P. 976-978.

11. Burr T.J., Reid C.L., Splittstoesser D.F., Yoshimura M. Effect of heat treatment on grape bud mortality and survival of Agrobacterium vitis 
in vitro and in dormant grape cuttings // Am. J. Enol. Vitic. - 1996. Vol. 47, № 2. - P. 119-123.

12. Burr T.J., Reid C.L., Tagliati E. et al. Biological control of grape crown gall by strain F2/5 is not associated with agrocin production or competition for attachment sites on grape cells // Phytopathology. - 1997. Vol. 87. - P. 705-711.

13. Burr T.J., Bazzi C., Sble S., Otten L. Crown gall of grape: biology of Agrobacterium vitis and the development of disease control strategies // Plant Dis. - 1998. - Vol. 82. - P. 1288-1297.

14. Burr T.J., Otten L. Crown gall of grape: biology and disease management // Annu. Rev. Phytopathol. - 1999. - Vol. 37. - P. 53-80.

15. Burr T.J., Reid C.L., Adams C.E., Momol E.A. Characterization of Agrobacterium vitis strains isolated from feral Vitis riparia // Plant Disease. - 1999. - Vol. 83, № 2. - P. 102-107.

16. Canaday J., Gerard J.C., Crouzet P., Otten L. Organization and functional analysis of three T-DNAs from the vitopine Ti plasmid pTiS4 // Mol. Ge. Genet. - 1992. - Vol. 235. - P. 292-303.

17. Caudwell A., Larrue J., Boudon-Padieu E., McLean G. D. Flavescence dorŭe elimination from dormant wood of grapevines by hot-water treatment // Australian J. Grape Wine Research. - 1997. - Vol. 3, № 1. P. 21-25.

18. Chen F., Guo Y.B., Wang J.H., Li J.Y., Wang H.M. Biological control of grape crown gall by Rahnella aquatilis HX2 // Plant Disease. - 2007. Vol. 91, № 8. - P. 957-963.

19. Chernin L.S., Lobanok E.V., Fomicheva V.V. et al. Crown gallsuppressive IncW $\mathrm{R}$ plasmids caused a decrease of auxin production in Agrobacterium tumefaciens // Mol. Gen. Genet. - 1984. - Vol. 195. P. 195-201.

20. Chilton M.D., Currier T.C., Farrand S.K., Bendich A.J., Gordon M.P., Nester E.W. Agrobacterium tumefaciens DNA and PS8 bacteriophage DNA not detected in crown gall tumors // Proc. Nat. Acad. Sci. USA. - 1974. Vol. 71, № 9. - P. 3672-3676.

21. Chilton M.-D., Drummond M.H., Merlo D.J., Sciaky D., Montoya A.L., Gordon M.P., Nester E.W. Stable incorporation of plasmid DNA into higher plant cells: the molecular basis of crown gall tumorigenesis // Cell. - 1977. - Vol. 11. - P. 263-271.

22. Clare B.G., Kerr A., Jones D.A. Characteristics of the nopaline catabolic plasmid in Agrobacterium strains K84 and K1026 used for biological control of crown gall disease // Plasmid. - 1982. - № 23. P. 126-137.

23. Creasap J.E., Reid C.L., Giffinet M.C., Aloni R., Ullrich C., Burr T.J. Effect of wound position, auxin, and Agrobacterium vitis strain F2/5 on wound healing and crown gall in grapevine // Phytopathology. - 2005. Vol. 95. - P. 362-367. 
24. Cubero J., Martinez M.C., Llop P., Lopez M.M. A simple and efficient PCR method for the detection of Agrobacterium tumefaciens in plant tumours // Journal of Applied Microbiology. - 1999. - Vol. 86. P. 591-602.

25. Cubero J., Wolf van der J., Beckhoven van J., Lopez M.M. An internal control for the diagnosis of crown gall by PCR // J. of Microbiol. Methods. - 2002. - Vol. 51, № 3. - P. 387-397.

26. Das B., Kundu J., Bachar S. C., Uddin M. A., Kundu J. K. Antitumor and antibacterial activity of ethylacetate extract of Ludwigia hyssopifolia Linn and its active principle piperine // Pak. J. Pharm. Sci. - 2007. Vol. 20, № 2. - P. 128-131.

27. De Cleene M., Ley J.D. The host range of crown gall // Bot. Rev. Vol. 42. - P. 389-466.

28. De Ley J., Gillis M., Pootjes C., Kersters K., Tytgat R., Braekel M. Relationship among temperate Agrobacterium phage genomes and coat proteins // J. Gen. Virol. - 1972. - Vol. 16. - P. 199-214.

29. Demaneche S., Kay E., Gourbiere F., Simonet P. Natural transformation of Pseudomonas fluorescens and Agrobacterium tumefaciens in soil // Appl. Environm. Microbiol. - 2001. - Vol. 67, № 6. - P. 2617-2621.

30. Dong L.C., Sun C.W., Thies K.L., Luthe D.S., Graves C.H. Use of polymerase chain reaction to detect pathogenic strains of Agrobacterium // Phytopathol. - 1992. - Vol. 82. - P. 434-439.

31. Donner S.C., Jones D.A., McClure N.C., Rosewarne G.M., Tate M.E., Kerr A., Fajardo N.N., Clare B.G. Agrocin 434, a new plasmid-encoded agrocin from the biocontrol Agrobacterium strains K84 and K1026, which inhibits biovar 2 agrobacteria // Physiol. Mol. Plant Pathol. - 1993. Vol. 42. - P. 185-194.

32. Eastwell K.C., Willis L.G., Cavileer T.D. A rapid and sensitive method to detect Agrobacterium vitis in grapevine cuttings using the polymerase chain reaction // Plant Disease. - 1995. - Vol. 79, № 8. P. 822-827.

33. Eastwell K.C., Sholberg P.L., Sayler R.J. Characterizing potential bacterial biocontrol agents for suppression of Rhizobium vitis, causal agents of crown gall disease of grapevines // Crop protection. - 2006. - 25, № 11. - P. 1191-1200.

34. Eayre C. Bacteriophage of Agrobacterium tumefaciens for the control of walnut crown gall. - 2003: http://www.ars.usda.gov/research/ publications/publications.htm?seq_no_115=147169.

35. Expert D., Tourneur J. $\psi$, a temperate phage of Agrobacterium tumefaciens, is mutagenic // J. Virol. - 1982. - Vol. 42. - P. 283-291.

36. Farrand S. K., Kado C. I., Ireland C. R. Suppression of tumorigenicity by the IncW R plasmid pSa in Agrobacterium tumefaciens // Mol. Gen. Genet. - 1981. - Vol. 181. - P. 44-51. 
37. Ferreira J.H.S., Zyl F.G.H. Susceptibility of grapevine rootstocks to strains of Agrobacterium tumefaciens biovar 3 // S. Afr. J. Enol. Vitic. 1986. - Vol. 7, № 2. - P. 101-104.

38. Frutos D., Cos J., Carrillo A. Are root knot nematodes (Meloidogine sp.) vector of Agrobacterium tumefaciens in Persian walnut seedlings. Proc. Joint Meeting of COST 873 (Murcia, Spain), 2007. - P. 16.

39. Goodman R.N., Grinm R., Frank M. The influence of grape rootstocks on the crown gall infection process and on tumor development // Am. J. Enol. Vitic. - 1993. - Vol. 44., № 1. - P. 22-26.

40. Goodner B.W., Markelz B.P., Flanagan C. et al. Combined genetic and physical map of the complex genome of Agrobacterium tumefaciens // J. Bacteriol. - 1999. - Vol. 181, № 17. - P. 5160-5166.

41. Haas J.H., Moore L.W., Ream W., Manulis S. Universal PCR primers for detection of phytopathogenic Agrobacterium strains // Appl. Environm. Microbiol. - 1995. - V. 61, № 8. - P. 2879-2884.

42. Haque N., Chowdhary S.A.R., Nutan M.T.H., Rahman G.M.S., Rahman K.M., Rashid M.A. Evaluation of antitumour activity of some medicinal plants of Bangladesh by potato disc bioassay // Fitoterapia. 2000. - Vol. 11, № 5. - P. 547-552.

43. Haviland D.R., Bentley W.J., Daane K.M. Hot-water treatments for control of Planococcus ficus (Homoptera: Pseudococcidae) on dormant grape cuttings // J. Econom. Entomol. - 2005. - Vol. 72. - P. 1109-1115.

44. Hayman G.T., Farrand S.K. Characterization and mapping of the agrocinopine-agrocin 84 locus on the nopaline Ti plasmid pTiC58 // J. Bacteriol. - 1988. - Vol. 170. - P. 1759-1777.

45. Hendson M., Askjaer L., Thomson J., Montagu M. van. Broadhost-range agrocin of Agrobacterium tumefaciens // Appl. Environm. Microbiol. - 1983. - Vol. 45, № 5. - P. 1526-1532.

46. Herlache T.C., Hotchkiss A.T., Burr T.J., Collmer A. Characterization of the Agrobacterium vitis pehA gene and comparison of the encoded polygalacturonase with the homologous enzymes from Erwinia carotovora and Pseudomonas (Burkholderia) solanacearum // Appl. Environm. Microbiol. - 1997. - Vol. 63. - P. 338-346.

47. Herlache T.C., Zhang H.S., Ried C.L., Carle S.A., Zheng D., Basaran P., Thaker M., Burr A.T. Burr T.J. Mutations that affect Agrobacterium vitis-induced necrosis also alter its ability to cause a hypersensitive response on tobacco // Phytopathol. - 2001. - Vol. 91. - P. 966-972.

48. Herlache T.C., Triplett E.W. expression of a crown gall biological control phenotype in an avirulent strain of Agrobacterium vitis by addition of the trifolitoxin production and resistance genes // BMC Biotechnology. 2002. - Vol. 2: http://www.biomedcentral.com/1472-6750/2/2

49. Hussain A., Zia M., Mirza B. Cytotoxic and antitumor potential of Fagonia cretica L. // Turk J. Biol. - 2007. - Vol. 31. - P. 19-24. 
50. Jones D.A., Ryder M.H., Clare B.G., Farrand S.K., Kerr A. Construction of a Tra- deletion mutant of pAgK84 to safeguard the biological control of crown gall // Mol. Gen. Genet. - 1988. - Vol. 212. - P. 207-214.

51. Kauffman M., Kassemeyer H.H., Otten L. Isolation of Agrobacterium vitis from grapevine propagating material by means of PCR after immunocapture cultivation // Vitis. - 1996. - Vol. 35. - P. 151-153.

52. Kawaguchi A., Sawada H., Inoue K., Nasu H. Multiplex PCR for the identification of Agrobacterium biovar 3 strains // J. Gen. Plant Pathol. 2005. - Vol. 71. - P. 54-59.

53. Kawaguchi A., Inoue K., Nasu H. Biological control of grapevine crown gall by nonpathogenic Agrobacterium vitis VAR03-1 // J. Gener. Plant Pathol. - 2007. - Vol. 73. - P. 133-138.

54. Kerr A., Roberts W.P. Agrobacterium: correlations between a transfer of pathogenicity, octopine and nopaline metabolism and bacteriocin 84 sensitivity // Physiol. Plant Pathol. - 1976. - Vol. 9. - P. 205-211.

55. Khmel I.A., Sorokina T.A., Lemanova N.B., Lipasova V.A., Metlitski O.Z. Biological control of crown gall in grapevine and raspberry by two Pseudomonas spp. with a wide spectrum of antagonistic activity // Biocontrol Sci. Technol. - 1998. - Vol. 8, № 1. - P. 45-57.

56. Konup L.A., Gayday A.E., Milkus B.N. Crown gall of grape in Ukraine // Odessa Nat. Univ. Herald. - 2001. - Vol. 6, № 4. - P. 181-183 (in Russian).

57. Krimi Z., Petit A., Mougel P. et al. Seasonal fluctuations and longterm persistance of pathogenic populations of Agrobacterium spp. in soils // Appl. Environm. Microbiol. - 2002. - Vol. 68, № 7. - P. 3358-3365.

58. Kumagai L., A.-L. Fabritius Detection and differentiation of pathogenic Agrobacterium vitis and A. tumefaciens in grapevine using multiplex Bio-PCR // 2th Annual National Viticulture Research Conference (Davis, USA, July 9 - 11, 2008). - Davis: University of California, 2008. P. 42-43.

59. Lastra B., Llop P., Lopez M.M. Characterization of Agrobacterium strains isolated from grapevine in Galicia (Spain) // Proc. Congress of the European Foundation for Plant pathology. - Taormina (Italy), 2000. P. 178-179.

60. Lehoczky J. Spread of Agrobacterium tumefaciens in the vessels of the grapevine after natural infection // Phytopathol. Z. - 1968. Vol. 63. - P. 239-246.

61. Liang Z.H., Wang H.M., Wang J.H. Preliminary study on effectiveness and the stability of E26 on controlling crown gall disease // J. China Agric. Univ. - 2001. - Vol. 6, № 1. - P. 91-95.

62. Llop P., Murrilo J., Lastra B., Lopez M. Recovery of nonpathogenic mutant bacteria from tumors caused by several Agrobacterium tumefaciens strains: a frequent event? // Appl. Environm. Microbiol. - 2009. - Vol. 75, № 20. - P. 6504-6514. 
63. Lopez-Lopez M.J., Vicedo B., Orellana N., Piquer J., Lopez M.M. Behavior of a virulent strain derived from Agrobacterium radiobacter strain K84 after spontaneous Ti plasmid acquisition // Phytopathology. - 1999. Vol. 89. - P. 286-292.

64. Mahmoodzadeh H., Nazemieh A., Majidi I., Paygami I., Khalighi A. Effects of thermotherapy treatments on systemic Agrobacterium vitis in dormant grape cuttings // J. Phytopathology. - 2003. - Vol. 151, № 9. P. 481-484.

65. Manulis S., Chalupowiez L., Dror O., Kleitman F. Molecular diagnostic procedures for production of pathogen-free propagation material // Pest Manag. Science. - 2002. - Vol. 58. - P. 1126-1131.

66. McClure N.C., Ahmadi A.R., Clare B.G. Construction of a range of derivatives of the biological control strain Agrobacterium rhizogenes K84: a study of factors involved in biological control of crown gall disease // Appl. Environm. Microbiol. - 1998. - Vol. 64, № 10. - P. 3977-3982.

67. Mongelli E., Romano A., Desmarchelier C., Coussio J., Ciccia G. Cytotoxic 4-nerolidylcathechol from Pothomorphe peltata inhibits topoisomerase I activity // Planta Med. - 1999. - Vol. 65. - P. 376-378.

68. Nesme X., Leclerc M.C., Bardin R. PCR detection of an original endosymbiont: the Ti plasmid of Agrobacterium tumefaciens / Endocytobiology IV / Nardon P., Gianinazzi-Pearson, Greines A.M., Margulis L., Smith D. - Paris: INRA, 1989. - P. 47-50.

69. Nusrat Jabeen, Sheikh A. Rasool, Samia Ahmad, Munazza Ajaz, Saeed Sadia. Isolation, identification and bacteriocin production by indigenous diseased plant and soil associated bacteria // Pakistan J. of Biol. Sciences. - 2004. - Vol. 7. - P. 1893-1897.

70. Ophel K., Nicholas P.R., Magarey P.A., Bass A.W. Hot water treatment of dormant grape cuttings reduces crown gall incidence in a field nursery // Am. J. Enol. Vitic. - 1990. - Vol. 41, № 4. - P. 325-329.

71. Penyalver R., Oger P., Lopez M.M., Farrand S.K. Iron-binding compounds from Agrobacterium spp.: biological control strain Agrobacterium rhizogenes K84 produces a hydroxamate siderophore // Appl. Environm. Microbiol. - 2001. - Vol. 67. - P. 654-664.

72. Pinkerton J.N., Ivors K.L., Miller M.L., Moore L.W. Effect of soil solarization and cover crops on populations of selected soilborn plant pathogens in Western Oregon // Plant Disease. - 2000. - Vol. 84, № 9. P. 952-960.

73. Ponsonnet C., Nesme X. Identification of Agrobacterium strains by PCR-RFLP analysis of pTi and chromosomal regions // Archive Microbiol. 1994. - Vol. 6. - P. 300-309.

74. Pu X.-A., Goodman R.N. Tumour formation by Agrobacterium tumefaciens is suppressed by Agrobacterium radiobacter HLB-2 on grapevine plants // Am. J. Enol. Vitic. - 1993. - Vol. 44, № 3. - P. 249-254. 
75. Pu X.A., Goodman R.N. Effects of fumigation and biological control on infection of indexed crown gall free grape plants // Am. J. Enol. Vitic. 1993. - Vol. 44, № 3. - P. 241-248.

76. Pulawska J., Willems A., Sobiczewski P. Rapid and specific identification of four Agrobacterium species and biovars using multiplex PCR // Syst. Appl. Microbiol. -2006. - Vol. 29, № 6. - P. 470-479.

77. Puopolo G., Raio A., Zoina A. Early detection of Agrobacterium tumefaciens in symptomless artificially inoculated chrysanthemum and peach plants using PCR // J. Plant Pathol. - 2007. - Vol. 89, № 2. P. 185-190.

78. Reader J.S., Phillip T. Ordoukhanian P.T., Jung-Gun Kim J.G., Crücy-Lagard V. de, Hwang I., Farrand S., Schimmel P. Major biocontrol of plant tumors targets tRNA synthetase // Science. - 2005. - Vol. 309, № 5740. - P. 1533 .

79. Rooney S.N., Gubler W.D. Effect of hot water treatments on eradication of Phaemoniella chlamydospora and Phaeacremonium inflatipes from dormant grapevine wood // Phytopathol. Mediterr. - 2001. - Vol. 40. P. 467-472.

80. Saadoun I., Hameed K.M., Al-Momani F., Ababneh O. Effect of three Orobanche spp. extracts on some local phytopathogens, Agrobacterium and Erwinia // Turk J. Biol. - 2008. - Vol. 32. - P. 1-5.

81. Saiki R.K., Gelfand D.H., Stofel S., Scharf S.J., Higuchi R., Horn G.T., Mullis K.B., Erlich H.A. Primer-directed enzymatic amplification of DNA with a thermostable DNA polymerase // Science. - 1988. Vol. 239. - P. 487-491.

82. Sawada H., Ieki H., Matsuda I. PCR detection of Ti and Ri plasmids from phytopathogenic Agrobacterium strains // Appl. Environ. Microbiol. 1995. - Vol. 61. - P. 828-831.

83. Schaad N.W., Cheong S.S., Tamaki S. et al. A combined biological and enzymatic amplification (Bio-PCR) technique to detect Pseudomonas syringae pv phaseolicola in bean seed extracts // Phytopathology. 1995. - Vol. 85. - P. 243-248.

84. Schulz T.F., Lorenz D., Eichorn K.W., Otten L. Amplification of different marker sequences for identififcation of Agrobacterium vitis strains // Vitis. - 1993. - Vol. 32. - P. 179-182.

85. Slota J.E., Farrand S.K. Genetic isolation and physical characterization of pAgK84, the plasmid responsible for agrocin 84 production // Plasmid. - 1982. - № 8. - P. 175-186.

86. Staphorst J.L., van Zyl F.G.H., Strijdom B.W., Groenewold Z.E. Agrocin-producing pathogenic and nonpathogenic biotype-3 strains of Agrobacterium tumefaciens active against biotype-3 pathogens // Curr. Microbiol. - 1985. - Vol. 12. - P. 45-52. 
87. Stockwell V.O., Moore L.W., Loper J.E. Fate of Agrobacterium radiobacter $\mathrm{K} 84$ in the environment // Appl. Environm. Microbiol. 1993. - Vol. 59, № 7. - P. 2112-2120.

88. Sule S., Lehoczky J., Jenser G., Nagy P., Burr T.J. Infection of grapevine roots by Agrobacterium vitis and Meloidogyne hapla // J. Phytopathology. - 1994. - Vol. 143. - P. 169-171.

89. Sule S., Moszar J., Burr T.J. Crown gall resistance of Vitis spp. and grapevine rootstocks // Phytopathology. - 1994. - Vol. 84, № 6. P. 607-611.

90. Sule S., Burr T.J. The effect of resistance of rootstocks to crown gall (Agrobacterium spp.) on the susceptibility of scions in grape vine cultivars // Plant Pathol. - 1998. - Vol. 47. - P. 84-88.

91. Suzaki K., Yoshida K., Sawada H. Detection of tumorigenic Agrobacterium strains from infected apple saplings by colony PCR with improved PCR primers // J. Gen. Plant Pathol. - 2004. - Vol. 70. P. 342-347.

92. Szegedi E., Bottka S. Detection of Agrobacterium vitis by polymerase chain reaction in grapevine bleeding sap after isolation on a semiselective medium // Vitis. - 2002. - Vol. 41, № 1. - P. 37-42.

93. Tan B.S., Yabuki J., Matsumoto S., Kageyama K., Fukui H. PCR primers for identification of opine types of Agrobacterium tumefaciens in Japan // J. Gen. Plant Pathol. - 2003. - Vol. 69, № 4. - P. 258-266.

94. Tate M.E., Murphy P.J., Roberts W.P., Kerr A. Adenine N7-substituent of agrocin 84 determines its bacteriocin-like specificity // Nature. 1979. - Vol. 280. - P. 797-799.

95. Tiefenbrunner W., Regner F., Mandl K., Leitner G., Gangl H. The wild vine (Vitis vinifera ssp. silvestris) in the riparian forests of Donau and March (Austria): evaluation of genetic divergence, presence of grape viruses, bacterials and soil-borne vectors // Plant Gen. Res. Newslett. 2005. - № 141. - P. 26-32.

96. Toklikishvili N., Dandurishvili N., Vainstein A., Tediashvili M., Giorgobiani N., Lurie S., Szegedi E., Glick B.R., Chernin L. Inhibitory effect of ACC deaminase-producing bacteria on crwon gall formation in tomato plants infected by Agrobacterium tumefaciens or A. vitis // Plant Pathol. - 2010. - Vol. 59, № 6. - P. 1023-1030.

97. Vicedo B., Penyalver R., Asins M.J., Lopez M.M. Biological control of Agrobacterium tumefaciens, colonization, and pAgK84 transfer with Agrobacterium radiobacter K84 and the Tra- mutant strain K1026 // Appl. Environm. Microbiol. - 1993. - Vol. 59. - P. 309-315.

98. Waite H., May P. The effect of hot water treatment, hydration and order of nursery operations on cuttings of Vitis vinifera cultivars // Phytopathol. Mediterr. - 2005. - Vol. 44. - P. 144-152. 
99. Waite H., Morton L. Hot water treatment, trunk diseases and other critical factors in the production of high-quality grape planting material // Phytopatol. Mediterr. - 2007. - Vol. 46. - P. 5-12.

100. Walls P.A., Pootjes C.F. Host-phage interaction in Agrobacterium tumefaciens IV. Phage-directed protein synthesis // J. Virol. - 1975. Vol. 15, № 2. - P. 372-378.

101. Wample R.L., Bary A., Burr T.J. Heat tolerance of dormant Vitis vinifera cuttings // Am. J. Enol. Vitic. - 1991. - Vol. 42, № 1. P. 67-72.

102. Wample L.R. Influence of pre- and post-treatment storage on rooting of hot-water-treated cuttings of Cabernet Sauvignon // Am. J. Enol. Vitic. - 1997. - Vol. 48, № 2. - P. 131-136.

103. Wang H.M., Wang H.X., Ng T.B., Li J.Y. Purification and characterization of an antibacterial compound produced by Agrobacterium vitis strain E26 with activity against A. tumefaciens // Plant Pathol. 2003. - Vol. 52. - P. 134-139.

104. Webster J., Santos M., Thomson J.A. Agrocin-producing Agrobacterium tumefaciens strain active against grapevine isolates // Appl. Environm. Microbiol. - 1986. - Vol. 52, № 1. - P. 217-219.

105. Xiaoying C., Wangnian X. A strain of Agrobacterium radiobacter inhibits growth and gall formation by biotype III strain of $A$. tumefaciens from grapevine // Acta Microbiol. Sin. - 1986. - Vol. 26. - P. 193-199.

106. Young J.M., Kuykendall L.D., Martinez-Romero E., Kerr A., Sawada H. A revision of Rhizobium Frank 1889, with an emended description of the genus, and the inclusion of all species of Agrobacterium Conn 1942 and Allorhizobium undicola de Lajude et al. 1998 as new combinations: Rhizobium radiobacter, $R$. rhizogenes, $R$. rubi, $R$. undicola and $R$. vitis // Int. J. of Syst. and Evolut. Microbiol. - 2001. - Vol. 51. - P. 89-103.

107. Yun L.J., Wang H.M., Wang J.H. A bacteriocin with a broad spectrum activity produced by grapevine crown gall biocontrol strain E26 // Sci. Agric. Sin. - 2004. - Vol. 37, № 12. - P. 1860-1865.

108. Zimmerer R.P., Hamilton R.H., Pootjes C. Isolation and morphology of temperate Agrobacterium tumefaciens bacteriophage // J. Bacteriol. 1966. - Vol. 92, № 3. - P. 746-750.

109. Zyl van F.G.H., Strijdom B.W., Staphorst J.L. Susceptibility of Agrobacterium tumefaciens strains to two agrocin-producing Agrobacterium strains // Appl. Environm. Microbiol. - 1986. - Vol. 52, № 2. P. 234-238. 
УДК 579.25:632.35:634.8.03/.05

\section{Н.В. Ліманська}

Одеський національний університет імені I.I. Мечникова, вул. Дворянська, 2, Одеса, 65082, Україна, e-mail: limanska@gmail.com

\section{ЗАХИСТ ВИНОГРАДУ ВІД БАКТЕРІАЛЬНОГО РАКУ}

\section{Реферат}

Розглянуто комплексні стратегії контролю бактеріального раку: відбір здорового садивного матеріалу, термотерапія, агротехніка, обробка хімічними речовинами та екстрактами рослин. Особливу увагу приділено біологічному контролю. Наведено короткий опис найбільш вивчених штамів-антагоністів. Висвітлено основні проблеми захисту винограду від бактеріального раку.

Ключові слова: бактеріальний рак, виноград, Agrobacterium vitis, Agrobacterium tumefaciens.

\section{УДК 579.25:632.35:634.8.03/.05}

\section{Н.В. Лиманская}

Одесский национальный университет имени И.И. Мечникова, ул. Дворянская, 2, Одесса, 65082, Украина, e-mail: limanska@gmail.com

\section{ЗАЩИТА ВИНОГРАДА ОТ БАКТЕРИАЛЬНОГО РАКА}

\section{Peфepat}

Рассмотрены комплексные стратегии контроля бактериального рака: отбор здорового посадочного материала, термотерапия, агротехника, обработка химическими веществами и экстрактами растений. Особенное внимание уделено биологическому контролю. Приведено краткое описание наиболее изученных штаммов-антагонистов. Освещены основные проблемы защиты винограда от бактериального рака.

Ключевые слова: бактериальный рак, виноград, Agrobacterium vitis, Agrobacterium tumefaciens.

Одержано 02.03.12 